form mesotrons. The investigations will be carried out under the direction of Dr. Lyman J. Briggs, chairman of the Research Committee of the National Geographic Society and formerly director of the National Bureau of Standards. The Army Air Force's co-operation in the project is under the supervision of Major-General Curtis E. Le May, deputy chief of staff in charge of research; the activities of the Bartol Research Foundation will be in charge of Dr. W. F. G. Swann.

\section{South African Council for Scientific and Industrial Research}

AN initial statement of the objects and policy of the South African Council for Scientific and Industrial Research (The Mint, Pretoria), dated December 1, 1945, has been published over the signature of Dr. B. F. J. Schonland. Emphasizing the need for research in South Africa, the statement points out that it has become essential for the Government to establish an organisation to advise it on the best method of developing resources in scientific manpower and equipment for research to the full, to co-ordinate scientific research for the national welfare and to take charge of certain developments which it considers are badly needed. These functions have been entrusted by the Scientific Research Council Act of 1945 to the Council for Scientific and Industrial Research, a corporate body responsible to the Prime Minister of the Union for formulating and imple. menting a national policy of scientific and industrial research.

The Council is to consist of a full-time president, who is its chief executive officer, and nine members chosen for their eminence in science and industry. The Council has been created with functions and powers similar to those found necessary for equivalent bodies by Great Britain, Canada, Australia and various Continental countries, and has been made a corporate body outside the Government service to give it the flexibility and freedom essential for scientific research ; but it is responsible to Parliament through the Prime Minister for its programme and estimates. Although the Council will derive its basic revenues from a Parliamentary vote, a substantial income is anticipated from other sources, and among the subjects for the development of which it is hoped gifts will be made are research in medicine and national health, special research fellowships, travelling research fellowships, and scientific research institutes, some of a Pan-African nature, in such subjects as meteorology, geochemistry, marine biology, ecology, genetics, nutrition, tropical diseases, oceanography and entomology.

Estimating that South Africa is at present spending about one-sixth of the amount which, in comparison with other countries, it should be spending on research, the statement suggests that industry itself in South Africa should be expending $£ 12,000,000$ a year on industrial research, leaving the State to provide $£ 3,000,000$ for research in other directions. Looking at the organisation of industrial research as a whole, the statement contemplates that the Council may advise industrialists as to subjects of research, and the Government on research expenditure which should be allowed for tax abatement; and it should foster research associations where desirable. A small number of national research laboratories are required to take over the long-range type of investigation, and the Council proposes to establish immediately a national physical laboratory, a national chemical research laboratory and a building research laboratory. It plans to foster the development of research in universities and similar institutions and to create conditions under which the best science students can be offered a reasonable livelihood in scientific research. In dealing with university research, the Council will direct special attention to encouraging research with no immediate practical object and to improving the conditions under which research is prosecuted and research workers are trained in the universities. The Council will also vigorously explore the needs of the country in the biological sciences basic to agriculture and medicine. It is proposed to develop an informa. tion service as a central library and information bureau of the Council, and to establish scientific missions in London, Washington and other centres, which might possibly be headed by scientific attaches.

\section{Research in Britain on Telecommunications}

Replying to a debate on telecommunications research raised on the adjournment on May 3, Mr. W. A. Burke, the Assistant Postmaster-General, agreed as to the necessity for increasing both the quantity and quality of such research carried out by the Post Office. He said that it is proposed to use the Dollis Hill premises to the full for research, and the training of engineers will be transferred to the Midlands. With an increase in staff and more accommodation, it will be possible for much more fundamental research to be prosecuted. Mr. Burke also stated that a British telephone technical develop. ment committee and the cable manufacturers' technical committee are working in conjunction with the Post Office, and a considerable amount of research has been carried out in this way. The Department of Scientific and Industrial Research has also set up a committee, with Sir Stanley Angwin, chief engineer of the Post Office, as chairman, "to formulate in detail the basic and fundamental research problems in telecommunications which require investigation". Referring to the development work, with which the Dollis Hill Station has hitherto been concerned, rather than with fundarnental research, Mr. Burke mentioned ultra-short-wave radio communications, co-axial cables, a scheme for the electro-mechanical facing of letters which would save a good deal of labour, and such war-time achievements as air-raid warning apparatus, specially designed telephone and telegraph circuits for military purposes, improvements to army signals equipment, and the development of equipment connected with defence against air attack.

\section{Talking with the Gullet}

THE removal of the larynx is a drastic operation, but the use of sulphonamide and penicillin have made it possible to prevent the sepsis which formerly hindered recovery (Lancet, March 2, p. 312) The operation involves loss of normal speech, and it is good to learn that remarkable progress has been made in teaching people who have lost the larynx to speak with the œesophagus. Speech can be produced by a stream of air which comes up through the oesophagus instead of through the trachea. The subject must first learn to swallow air. It is not essential that he should do this before the operation, but it is better if he does so. A week or so before the larynx is removed, he is taught to close the glottis and the lips and to expand the chest as he swallows, so that air is aspirated; this can then be brought up again in a noisy belch. When the operation wound has 
healed, the swallowing of air and belching is resumed. The trick of this may be learned more easily if a boiled sweet is sucked or if the subject takes acid and alkaline powders which give off gas in the stomach. Very soon it becomes possible to convert the belching of wind into something like speech. Consonants such as sh and ch are usually the first to be practised. Vowels are then added to them and words like church and scrub are made. When such explosive consonants as $p, d$ and $k$ have been learnt, other words are added. Before long, several syllables, or one long word, can be spoken with each intake of air, and attempts are then made at short sentences. Pauses for the intake of air cause abnormal grouping of words, and this difficulty is only slowly overcome.

The mechanism of this remarkable achievement has been investigated by asking the subject to swallow a thick barium paste which adheres to the walls of the pharynx and œsophagus so that it can be studied radiographically. It has been found that usually the œsophagus is the air reservoir, but at least one subject used the stomach as an additional one. During speech a narrow channel in the hypopharynx acts as a pseudo-glottis. Photographs of œsophageal speech have been taken by asking the subject to speak into a microphone connected to a cathode ray oscillograph. These show that the pseudo-glottis vibrates very irregularly, and this explains why the cesophageal voice is husky and indefinite in pitch. It has been claimed, however, that a few subjects have learned to modulate their œesophageal voices through a few tones or even through an octave. Subjects who have learnt to speak in this way perform a valuable service by teaching others.

\section{Early Management of Sown Pastures}

Butletin 34 of the Imperial Bureau of Pastures and Forage Crops, Aberystwyth (obtainable from the Bureau, Central Sales Branch, Penglais, Aberystwyth. 7s.), "The Establishment and Early Management of Sown Pastures", has been prepared in collaboration with the Bureau of Plant Industry, Soils and Agricultural Engineering, and the Forest Service of the United States Department of Agriculture, Wash. ington, D.C. It consists of articles, each written by experts, from Great Britain, Canada, Australia, Now Zealand and the United States, dealing with that period of grassland husbandry which extends from the preparation of the soil and the composition of the seeds mixture to the management of the sward in its early years. Since the establishment and management of pastures in the tropics have recently been described in Bulletin 31, the discussion here is chiefly confined to the temperate zone, though climatic conditions ranging from semi-arid to humid are covered. The technique of grassland husbandry has been developed as a result of scientific experimentation and trials on a farm basis. The details of this technique, however, vary widely according to the soil, natural vegetation, climate and the purpose for which the herbage is being grown, whether it be for establishing temporary leys in crop rotations, swards on newly cleared forest land or for ground cover on eroded areas. Crop agronomists everywhere will find much of value and interest in the publication, and the large number of photographs included convey a good impression of the country described by each author. An index of the genera and species and a key to the common plant names are useful features of the bulletin.

\section{Marine Biology in the Pacific}

THE eastern tropical Pacific has been visited by collectors in a spasmodic manner for a number of years when scientific expeditions in these regions took dredgings at vàrious points or when, as Darwin did in 1835, parties visited the Galapagos Islands. Between 1931 and 1941 a series of ten expeditions was made under the Allan Hancock Foundation, which explored the region more fully and more systematically. The expeditions under the command of Captain Hancock were carried out in the Velero III, a Diesel-propelled cruiser of 1,300 tons with a speed of $14 \mathrm{knots}$ and a cruising range of 9,500 miles. She was specially designed and built for the work and fully equipped not only for biological but also for hydrographical work. The first volume of the reports of these voyages is by Prof. C. McLean Fraser (Allan Hancock Pacific Expeditions, Univ. Southern California Press, 1943) and consists of three parts. Part 1 includes the history of the scientific exploration of the region, a detailed description of the Velero III, and gives the personnel of each of the cruises. Part 2 treats of the geographical and biological associations. Part 3 provides a general account of the work done together with a list of all the collecting stations with the relevant data. All three parts are very well printed and illustrated with plentiful maps and many splendid plates. We look forward to the appearance of the volumes dealing with the collections made, for if they maintain the standard of the first volume they will form a noteworthy contribution to marine biology.

\section{Carnegie Museum}

THE forty-seventh annual report of the Carnegie Museum covers the year ended December 31, 1944, and includes the financial statement as well as a note on publications and on the library and museum (Carnegie Institute, Pittsburgh). Several projects in the field were either sponsored or conducted by the Museum. Dr. A. C. Twomey and Mr. O. F. von Fuehrer visited the west coast of Hudson Bay, near Churchill, where they secured a splendid set of caribou and a few birds of special interest. Dr. J. LeRoy Kay and Mr. J. K. Doutt spent two months in Montana, where they obtained the best collection of big game mammals which the Museum had collected in one venture. In researches in vertebrate palæontology in Montana during the summer months on a somewhat different plan from that of preceding years, numerous new species of fossils were collected, and the material on certain Tertiary forms like marsupials and insectivores from a type locality of the Pipestone Springs Chadron formation was practically doubled. Preliminary plans were made for a far-reaching project for a biological exploration on the northern sector of Labrador or the Ungava Peninsula. The most spectacular display of the year in the galleries was devoted to an interpretation of the Asiatic and Pacific theatres of war from the point of view of the natural history and the distribution of indigenous peoples. The growth of the collections and researches based on a series of scientific specimens have steadily advanced, and some improvements have been made in the laboratories. Educational services were somewhat reduced in scope owing to transport difficulties but were carried on substantially as before. The director's report is supplemented by more detailed sectional accounts of developments and activities. 